\title{
Effect of Potassium Fertilization and Foliar application of Compound Fertilizer on Growth, Yield and Root Quality of Beetroot under Clay Soil conditions
}

\author{
Shafeek M.R. ${ }^{1}$., Asmaa R. Mahmoud ${ }^{1}$, Y. I. Helmy ${ }^{1}$, Nadia M. Omar ${ }^{1}$, Soad, M. El- \\ Ashry $^{2}$ and Camilia Y.El-Dewiny ${ }^{2}$ \\ ${ }^{1}$ Vegetable Res. Dept., Agricultural and Biological Research Division, National Research Centre, 33 \\ El Buhouth St., 12622 Dokki, Giza, Egypt. \\ ${ }^{2}$ Soils and Water Res. Dept., Agricultural and Biological Research Division, National Research \\ Centre, 33 El Buhouth St., 12622 Dokki, Giza, Egypt.
}

Received: 03 June $2021 \quad$ Accepted: 10 July $2021 \quad$ Published: 15 July 2021

\begin{abstract}
Two field experiments were carried out at private farm in Qalyobia Governorate, Egypt during the two successive winter seasons of 2016/2017 and 2017/2018. The study aimed to investigate the effect of potassium soil fertilizer levels $\left(0,50\right.$ and $100 \mathrm{~kg} \mathrm{~K}_{2} \mathrm{O} /$ fad. $)$ and foliar spray with nutrient compound (Aquacool) on growth, yield and root quality of beetroot plants cv Balady grown in clay soil conditions. The gained results indicated that, the interaction between fertilizing beetroot with potassium at $100 \mathrm{~K}_{2} \mathrm{O} / \mathrm{fad}$. in the regulate potassium sulfate and spraying with high levels $(2 \mathrm{~cm} / \mathrm{L})$ of nutrient compound (Aquacool) gave the highest values of plant height, number of leaves/ plant, leaves fresh and dry weight, total roots yield and its components (root weight, length and diameter) as well as highest contents of the percentage of $\mathrm{N}, \mathrm{P}, \mathrm{K}$, total sugar and vitamin $\mathrm{C}$ in root tissue.
\end{abstract}

Keywords: Beetroot. Potassium soil fertilizer, Aquacool, growth, yield and quality

\section{Introduction}

Beetroot is a cool weather crop, produced for its leafy greens and roots. It is rich in active compounds such as carotenoids, glycine, betaine, betacyanines, folates, betanin, polyphenols, and flavonoids (Dias et al., 2009). Beetroots can be used together with other vegetables in the form of salads, or consumed commercially as a dye to color processed food. The roots of beetroot are also used as a nutrient supplement and as a canned product.

Now in Egypt, there are much foliar fertilizers containing the maximum macro and micro elements mostly applied to correct any deficiency in soil. So, foliar sprays overcome this affair (Hegab et al., 1987). On the other hand, Hassan et al., (2013) found that, sprinkle with both Fe and $\mathrm{Zn}$ gave significantly beneficent in total yield and $\mathrm{Fe}, \mathrm{Zn}$ and $\mathrm{K}$ uptake of plants. The mechanism action of these nutrients in metabolism process was described by (Savitha 2008) as he reported that, the application of some minerals as foliar spray improved plant growth, fruit yield and its physical and chemical property of crops. In the same respect, Bhatt et al., (2004) found the influence of foliar application of micronutrients on yield and economics and direction of tomato. They reported that foliar application of $\mathrm{Fe} \mathrm{SO}_{4}$ at 0.01 per cent achieved significant increase in yield per ha which might be attributed to improving photosynthetic efficiency and increased reproduction and collection of carbohydrate. However, Shafeek et al., (2013) reported that foliar spray with various levels of nutritional compound Stimufol significantly increased the plant growth characters namely plant height, number of leaves and branches, fresh and dry weight of leaves and branches as well as whole plants also increased pod length, average weight of pod and total yield as ton/fed and it gave the highest values of the percentage of protein and nitrogen as well as Fe and $\mathrm{Mn}$ (mg/g dry weight) of broad bean seeds with superiority by application of high level (200 g/fed.). However, Shafeek, et al., (2014) reported that the vigor plant growth such as number of leaves/plant and net assimilation rate 
(NAR) and the highest total fruits yield and its components as well as the high content of the percentage of $\mathrm{N}, \mathrm{K}$ and protein of hot pepper fruits tissues were obtained with that plants which sprayed by nutritional fertilizers at concentration of $3 \mathrm{~L} /$ fed. Moreover, Shafeek, et al., (2018) gained results specified that the strength plant growth such as plant length, number of leaves/plant and fresh weight of leaves per plant and the highest total bulbs yield and its ingredient (bulb and neck diameter, number and weight of clove and TSS \%) as well as the high content of the percentage of N, P, K and protein of garlic cloves tissues were detected with that plants which sprayed as nutritional (Aquacool) at highest concentrations $(2 \mathrm{~cm} / \mathrm{L})$.

Potassium is a main plant nutrient, which is necessary by the plants in major neutralize and is supplied by the fertilizer. It is obtainable to the plants in organize of cation $(\mathrm{k}+)$. Really potassium is essential for a diversity of operation i.e. photosynthesis, fruit formation, winter hardiness and disease resistance. It plays an important role in protein formation. Moreover, the complete root crops considerably rely to the potassium application. However, Yadav et al., (2003) noticed significantly higher onion yield of bulb and fresh weight of bulbs with implementation of $150 \mathrm{~kg} \mathrm{~K}_{2} \mathrm{O} / \mathrm{ha}$ over other potassium levels. Moreover, considering economics of crops neutral use of $\mathrm{K}_{2} \mathrm{O}$ fertilizers at 50 $\mathrm{kg} / \mathrm{ha}$ gave the optimum finding (Tiwari et al., 2003). Increasing levels of potassium significantly improve TSS (11.99\%) content of onion bulb was gained in the treatment receiving K at $125 \mathrm{~kg} / \mathrm{ha}$. While the maximum ascorbic acid content $(9.93 \mathrm{mg} / 100 \mathrm{~g}$ ) was recorded with $50 \mathrm{~kg} \mathrm{~K} 2 \mathrm{O} / \mathrm{ha}$. AbdElAal et al., (2005) and AbouEl-Nasr and Ibrahim (2011) reported that the highest potassium fertilization rate $(75 \mathrm{~kg} \mathrm{~K} 2 \mathrm{O} / \mathrm{fed}$.) gave the tallest shoot, the highest number of leaves per plant and the highest fresh weight of shoots as well as the highest total yield per fed. Also root length, root diameter, root weight, TSS and carotenoids content, as well as leaves chemical composition (N, P and $\mathrm{K}$ concentrations) were increased by increasing potassium fertilization rate. However, Saud et al., (2013) found that the maximum onion plant height $(51.6 \mathrm{~cm})$, number of leaves plant $(9.89)$, bulb diameter (5.93), average bulb weight $(64.89 \mathrm{~g})$, leaf width $(1.33 \mathrm{~cm})$ and yield $(22.91 \mathrm{ton} / \mathrm{ha})$ were spotted with the application of the highest level $\left(120 \mathrm{~kg} \mathrm{~K}_{2} \mathrm{O} / \mathrm{ha}\right)$. In the same respect, Shafeek, et al., (2013) reported that the highest onion plant vegetative growth character (the tallest plant, the highest leaves number, the heaviest fresh, dry weight of whole plant, total bulbs yield per unit area and dimension of bulb as well as its average weight) were achieved with using potassium sulfate at the highest rate $(300 \mathrm{~kg} / \mathrm{fed}$.). Also, highest nutritional values of bulb tissues from the percentage of TSS, protein, N, P, K, Fe, Mn, $\mathrm{Zn}$ and $\mathrm{Cu}$ and gained the highest bulb values of growth promoting phyto hormones expressed as $\mathrm{mg} / \mathrm{g}$ fresh weight of gibberellins and IAA and the lowest value of ABA as growth retardant. In the same respect, Shafeek, et al., (2015) recorded that, increasing potassium fertilizer levels significantly increased plant growth characters, total root yield and its components as well as the root contents of nitrogen, protein, $\mathrm{P}, \mathrm{K}$ and total carbohydrate contents.

\section{Materials and Methods}

Two field experiments were conducted on a private farm in Qalyobia Gavernorate Egypt during the two growing seasons of 2017 and 2018 in order to study the effect of the addition of different levels of potassium fertilizer potassium sulfate $(0,50$ and $100 \mathrm{~kg} / \mathrm{fed}$.) with various concentrations of nutritional compound (Aquacool) foliar application at $(0,1$ and $2 \mathrm{~cm} / \mathrm{L}$.) on vegetative growth, root yield characters and root quality of beetroot plants (Beta vulgaris L.) cv. Balady. The physical and chemical properties of soil are shown in Table (1).

Table 1: Physical and chemical properties of the experimental soil during both seasons.

\begin{tabular}{|c|c|c|c|c|c|c|c|c|c|c|}
\hline \multirow{2}{*}{$\begin{array}{l}\text { Depth } \\
\text { (cm) }\end{array}$} & \multirow[t]{2}{*}{ pH } & \multirow[t]{2}{*}{ Texture } & \multicolumn{3}{|c|}{ Anions (mg/100g soil) } & \multicolumn{4}{|c|}{ Cations (mg/100g soil) } & \multirow{2}{*}{$\begin{array}{l}\text { Total nitrogen } \\
\mathrm{Mg} / \mathrm{100g}\end{array}$} \\
\hline & & & $\mathbf{C i}$ & $\mathbf{P}$ & SO4 & $\mathrm{Na}$ & $\mathbf{K}$ & $\mathbf{C a}$ & Mg & \\
\hline $0-15$ & 8.1 & clay loam & 0.52 & 4.8 & 2.20 & 1.50 & 0.15 & 9.00 & 0.50 & 123.00 \\
\hline $15-30$ & 8.1 & clay loam & 0.38 & 5.6 & 1.60 & 1.20 & 0.07 & 4.00 & 0.25 & 137 \\
\hline
\end{tabular}

Aquacool is a commercial product containing macro nutrients such as $\mathrm{N}(7 \%), \mathrm{P}(5 \%), \mathrm{K}(5 \%)$, $\mathrm{Mg}(1 \%)$ and micro nutrients such as $\mathrm{B}(0.05 \%), \mathrm{Fe}(0.3 \%)$ and $\mathrm{S}(2.1 \%)$ as well as amino acids. Phosphorus $\left(\mathrm{P}_{2} \mathrm{O}_{5}\right)$ was applied $100 \mathrm{~kg} /$ fed. each at the time of soil preparation. Seeds of beetroot 
were obtained from Horticultural Research Institute, Agriculture Research Center. Seeds were sown on September $20^{\text {th }}$ and $26^{\text {th }}$ in 2017 and 2018, respectively. The area of experimental plot was $10.5 \mathrm{~m}^{2}$. Every plot consisted of 5 lines $3 \mathrm{~m}$ in length and $0.7 \mathrm{~m}$ in width. Seeds were sown in hills $10 \mathrm{~cm}$ apart on one side of lines and two seeds per hill. The normal agriculture practices of beetroot were followed according to the recommendations of Agriculture Ministry. The levels for nitrogen fertilizer were applied during plant growth in a split plot design with three replicates, potassium sulfate treatments occupied the main plots, while foliar application of Aquacool were distributed randomly in the sub plots. However, foliar spraying of Aquacool was applied after 20 days from sowing date, every 10 day's intervals for three times. This experiment included 9 treatments which included all combinations between the three levels of potassium sulfate fertilizers $(0,50$ and $100 \mathrm{~kg} /$ fed.) with three Aquacool levels $(0,1$ and $2 \mathrm{~cm} \backslash \mathrm{L}$.). At the vegetative growth stage, random samples of five plants from each plot were taken 60 days from sowing for determination of plant length $(\mathrm{cm})$, number of leaves per plant as well as, fresh and dry weight ( $\mathrm{g}$ ) of leaves /plant. Also, root organs (fresh weight) and some physical properties of root (diameter and length) were measured. Nutritional elements at harvesting time beetroot roots samples from each plot were taken for elemental analysis, N, P, and K in the dry matter of root tissue were determined according to the methods described by Pregl (1945); Troug and Mayer (1939) and Brown and Lilleland (1946), respectively. However, total crude protein \%, total sugar and ascorbic acid were determined according to AOAC (1975). All obtained data were subjected to the statistical analysis and means were compared according to LSD at 5\% level test described by Gomez and Gomez (1984).

\section{Results and Discussion}

\subsection{Growth characters}

\subsubsection{Effect of potassium soil fertilizer}

Data given in Table (2) show that potassium as soil fertilizer had a significant effect on plant growth parameters, i.e., plant length, number of leaves/plant, fresh and dry weight of beetroot leaves compared to control treatment. However, the highest plant growth characters were recorded with soil fertilizer of $100 \mathrm{~kg} / \mathrm{fed}$. of potassium sulfate fertilizer compared to all treatments. These findings were right in jointly seasons. This consequence may be due to the role of potassium element in metabolism and much practicability prerequisite to tolerate and elevate plant vegetative growth and development. Moreover, $\mathrm{K}$ plays a major role in many physiological and biochemical practicability likes cell segmentation and protraction and metabolism of carbohydrates and protein synthesis Marschner (1995). The acquired results are in a good conformity with those registered by Abd El-Aal et al., (2005), Abou El-Nasr and Ibrahim (2011), Saud et al., (2013), Shafeek et al., (2013), Awatef Behairy et al., (2015) and Shafeek, et al., (2016) who found that increasing potassium fertilizer levels increased plant height, number of leaves per plant and leaves fresh weight as well as plant dry weight of onion and garlic plants.

\subsubsection{Effect of foliar spray of nutrient compound (Aquacool) levels:}

Data in Table (2) showed that foliar spray with different concentrations of nutrient compound (Aquacool) significantly increased the growth characters expressed as plant height, number of leaves, fresh and dry weight of leaves liken to control (water) in the two growing seasons. However, the most adequate effect in this concern was addition Aquacool at level up to $(2 \mathrm{~cm} / \mathrm{L})$. On the other hand, it significantly increased plant length, number of leaves per plant, fresh and dry weight of leaves liken to lower level of Aquacool $(1 \mathrm{~cm} / \mathrm{L})$. These results were true in the two seasons. The notability of highest levels of Aquacool up to $(2 \mathrm{~cm} / \mathrm{L})$ in improving plant growth may be due to its high contents of macro and micro nutrients. This is perhaps due to providing the plants with desired nutrients which may one or more of them were insufficiently provide through the root system in such low fertile soil. During the last decades, foliar feeding of nutrients has become a determined transaction in crop 
Table 2: Effect of potassium sulfate levels with spray of nutritional compound (Aqucool) on plant growth characters during 2017 and 2018 seasons.

\begin{tabular}{|c|c|c|c|c|c|c|c|c|c|}
\hline \multirow{3}{*}{$\begin{array}{c}\text { Potassium } \\
\text { sulfate } \\
\text { (Kg/fed.) }\end{array}$} & \multirow{3}{*}{$\begin{array}{c}\text { Spray } \\
\text { Aqucool } \\
(\mathrm{cm} / \mathrm{L})\end{array}$} & \multicolumn{4}{|c|}{2017 season } & \multicolumn{4}{|c|}{2018 season } \\
\hline & & \multirow{2}{*}{$\begin{array}{c}\text { Plant } \\
\text { length } \\
\text { (cm) }\end{array}$} & \multirow{2}{*}{$\begin{array}{l}\text { No. of } \\
\text { leaves/ } \\
\text { plant }\end{array}$} & \multicolumn{2}{|c|}{ Wight (g) } & \multirow{2}{*}{$\begin{array}{l}\text { Plant } \\
\text { length } \\
(\mathrm{cm})\end{array}$} & \multirow{2}{*}{$\begin{array}{l}\text { No. of } \\
\text { leaves } \\
\text { /plant }\end{array}$} & \multicolumn{2}{|c|}{ Wight (g) } \\
\hline & & & & fresh & dry & & & fresh & dry \\
\hline \multirow{3}{*}{ Without } & 0 & 36.67 & 6.67 & 41.14 & 5.14 & 41.00 & 6.67 & 42.00 & 4.81 \\
\hline & 1 & 42.67 & 7.33 & 44.81 & 5.60 & 49.00 & 7.67 & 45.00 & 5.34 \\
\hline & 2 & 46.00 & 7.67 & 50.71 & 7.22 & 52.00 & 7.67 & 55.67 & 6.89 \\
\hline \multirow[t]{2}{*}{ Mean } & & 41.78 & 7.22 & 45.55 & 5.99 & 47.33 & 7.33 & 47.56 & 5.68 \\
\hline & $\mathbf{0}$ & 39.00 & 8.33 & 48.07 & 5.98 & 44.00 & 8.67 & 47.28 & 5.65 \\
\hline \multirow[t]{2}{*}{50} & 1 & 45.33 & 8.67 & 53.11 & 6.68 & 50.00 & 9.67 & 52.28 & 6.35 \\
\hline & 2 & 48.67 & 9.33 & 67.71 & 8.21 & 52.33 & 10.33 & 67.71 & 7.88 \\
\hline \multirow[t]{2}{*}{ Mean } & & 44.33 & 8.78 & 56.29 & 6.96 & 48.78 & 9.56 & 55.76 & 6.62 \\
\hline & $\mathbf{0}$ & 39.33 & 10.00 & 58.71 & 8.09 & 46.00 & 9.33 & 56.92 & 7.75 \\
\hline \multirow[t]{2}{*}{100} & 1 & 46.33 & 11.00 & 70.67 & 8.67 & 51.67 & 10.67 & 80.05 & 8.34 \\
\hline & 2 & 49.00 & 11.33 & 83.75 & 10.47 & 53.67 & 11.67 & 91.76 & 10.14 \\
\hline \multirow[t]{2}{*}{ Mean } & & 44.89 & 10.78 & 71.04 & 9.08 & 50.44 & 10.56 & 76.24 & 8.74 \\
\hline & $\mathbf{0}$ & 38.33 & 8.33 & 49.30 & 6.40 & 43.67 & 8.22 & 48.73 & 6.07 \\
\hline \multirow[t]{2}{*}{ Average } & 1 & 44.78 & 9.00 & 56.19 & 6.99 & 50.22 & 9.33 & 59.11 & 6.67 \\
\hline & 2 & 47.89 & 9.44 & 67.39 & 8.63 & 52.67 & 9.89 & 71.71 & 8.30 \\
\hline \multirow{3}{*}{$\begin{array}{l}\text { LSD at } \\
\text { 5\% level }\end{array}$} & Potassium & 1.57 & 0.36 & 3.44 & 0.39 & 1.28 & 0.36 & 5.49 & 0.37 \\
\hline & Aquacool & 1.79 & 0.43 & 3.05 & 0.58 & 0.81 & 0.31 & 3.20 & 0.58 \\
\hline & Interaction & NS & NS & NS & NS & NS & NS & 5.53 & NS \\
\hline
\end{tabular}

Production to increase yield and improve the quality of crop output (Roemheld and El-Fouly, 1999). Foliar application of nutrients could progress the nutrient employment and depress environmental pollution through decreasing the account of fertilizers added to soil (Abou-El-Nour 2002). The acquired outcome are in good conformity with these which gained by (El Fouly et al., 2010, Bozorgi et al., 2011, El-Habbasha et al., 2012 ,Shafeek et al., 2013 and 2018).

\subsubsection{Effect of interaction on potassium and nutrient compound}

Concerning with the interaction of both factors, the data in Table (2) indicated that, vegetative growth of beetroot plants was not significantly affected in two seasons except leaves fresh weight in the second season. Generally, in spite of the un-significant response, but the acquired data found that the highest values of plant growth standard were reported when sprayed by highest concentration of Aquacool up to $(2 \mathrm{~cm} / \mathrm{L})$ with high soil fertilizer of potassium sulfate $(100 \mathrm{~kg} / \mathrm{fed}$. $)$ to the other interaction treatments. These results held well in both two experimental seasons.

\subsection{Total yield and its components}

\subsubsection{Effect of potassium soil fertilizer}

The obtained data for potassium soil fertilizer revealed that highest total roots yield (15.400 and $15.551 \mathrm{ton} /$ fed.) for $1 \mathrm{st}$ and $2 \mathrm{nd}$ seasons, respectively were recorded with complement soil potassium fertilizer at rate of $100 \mathrm{~kg} /$ fed. (Table 3) followed by ( 15.000 and $14.398 \mathrm{ton} / \mathrm{fed}$.) with using of 50 $\mathrm{gk} / \mathrm{fed}$. while the least yield (13.887 and 13.177 ton / fed.) was registered in control treatment. The response of root weight, root length and diameter of beetroot follow the same trend like that mentioned above. It could be concluded that, the large roots yield and its component it might be attributed to the best activity of plant growth characters which gained by soil fertilizer by $100 \mathrm{~kg} / \mathrm{fed}$. of potassium sulfate (Table 3). Also, potassium element is very important in outright metabolism of plant enzymes efficiency, it was found to avail a indispensable role in photosynthesis by forthright increasing in growth and total root yield. Also, potassium has an advantageous effect on water exhaustion (Marschner, 1995). The same conclusion was also consummated by Ghaffoor et al., 
(2003), Khan et al., (2003), Pervez et al,( 2004) and Ali et al., (2007) who declared that as potash level increases up to optimum rates the yield (ton / fed.) and its ingredient increases.

\subsection{Effect of foliar spray of nutrient compound (Aquacool) levels}

Data approaching in Table (3) shows that foliar spray of different levels of nutritional compound (Aquacool) significantly increased average weight of root, root length and diameter as well as total roots yield as ton/fed. compared to the untreated treatment (control). Foliar spraying of high levels of nutritional fertilizer $(2 \mathrm{~cm} / \mathrm{L}$.) recorded its highest values on total yield (15.973 and 15.258 ton/fed.) for 1 st and 2 nd seasons respectively (Table 3 ). This means that, both yield and vegetative growth were affected by the same degree by foliar spray with the different levels of nutrient compound (Aquacool). These results are apparently due to the role of micronutrients and the other macro elements in the nutrient compounds affecting the metabolic process and in turn in plant growth and total yield. Foliar application of micronutrients seems to stimulate the metabolic process within the plant through their direct effect on the enzymatic reactions (Peyve 1969). Foliar feeding of a nutrient might have actually promoted root absorption of the same nutrient or other nutrients through improving root growth and increasing nutrients uptake (El-Fouly and El-Sayed, 1997). However, the trend of obtained results are in good accordance with that of the previous investigators such as (El Fouly et al., 2010, Bozorgi et al., 2011 and El-Habbasha et al., 2012) of crops.

Table 3: Effect of potassium sulfate levels with spray of nutritional compound (Aqucool) in total yield and its components during 2017 and 2018 seasons.

\begin{tabular}{|c|c|c|c|c|c|c|c|c|c|}
\hline \multirow{3}{*}{$\begin{array}{l}\text { Potassium } \\
\text { sulfate } \\
\text { (gk/fed.) }\end{array}$} & \multirow{3}{*}{$\begin{array}{l}\text { Spray } \\
\text { Aqucool } \\
\text { (cm/L) }\end{array}$} & \multirow{3}{*}{$\begin{array}{c}\text { Total } \\
\text { yield } \\
\text { (ton/fed.) }\end{array}$} & \multicolumn{3}{|c|}{2017 season } & \multirow{3}{*}{$\begin{array}{c}\text { Total } \\
\text { yield } \\
\text { (ton/fed.) }\end{array}$} & \multicolumn{3}{|c|}{2018 season } \\
\hline & & & \multirow{2}{*}{$\begin{array}{c}\text { Root } \\
\text { weight } \\
\text { (g) }\end{array}$} & \multicolumn{2}{|c|}{$\operatorname{Root}(\mathrm{cm})$} & & \multirow{2}{*}{$\begin{array}{c}\text { Root } \\
\text { weight } \\
\text { (g) }\end{array}$} & \multicolumn{2}{|c|}{$\operatorname{Root}(\mathrm{cm})$} \\
\hline & & & & Length & Wide & & & Length & Wide \\
\hline \multirow{3}{*}{ Without } & $\mathbf{0}$ & 12.883 & 76.60 & 12.00 & 4.30 & 12.167 & 73.26 & 11.00 & 3.70 \\
\hline & 1 & 14.080 & 90.90 & 13.00 & 4.53 & 13.430 & 93.45 & 12.00 & 3.93 \\
\hline & 2 & 14.667 & 98.02 & 14.67 & 4.83 & 13.933 & 96.45 & 12.67 & 4.27 \\
\hline \multirow[t]{2}{*}{ Mean } & & 13.887 & 88.50 & 13.22 & 4.56 & 13.177 & 87.72 & 11.98 & 3.97 \\
\hline & $\mathbf{0}$ & 13.500 & 80.03 & 12.33 & 4.65 & 13.257 & 77.57 & 12.67 & 4.51 \\
\hline \multirow[t]{2}{*}{50} & 1 & 14.947 & 95.24 & 14.33 & 4.90 & 14.697 & 96.74 & 13.67 & 4.67 \\
\hline & 2 & 16.553 & 108.12 & 15.67 & 5.50 & 15.240 & 106.45 & 15.00 & 4.87 \\
\hline \multirow[t]{2}{*}{ Mean } & & 15.000 & 94.46 & 14.11 & 5.02 & 14.398 & 93.59 & 13.78 & 4.68 \\
\hline & $\mathbf{0}$ & 13.667 & 123.93 & 14.33 & 5.57 & 14.203 & 107.30 & 14.00 & 5.27 \\
\hline \multirow[t]{2}{*}{100} & 1 & 15.833 & 134.14 & 16.00 & 5.93 & 15.850 & 122.73 & 15.67 & 5.57 \\
\hline & 2 & 16.700 & 147.72 & 17.33 & 6.10 & 16.600 & 139.21 & 16.67 & 5.73 \\
\hline \multirow[t]{2}{*}{ Mean } & & 15.400 & 135.26 & 15.89 & 5.87 & 15.551 & 123.08 & 15.44 & 5.52 \\
\hline & $\mathbf{0}$ & 13.350 & 93.52 & 12.89 & 4.84 & 13.209 & 86.04 & 12.56 & 4.49 \\
\hline \multirow[t]{2}{*}{ Average } & 1 & 14.953 & 106.76 & 14.44 & 5.12 & 14.659 & 104.31 & 13.78 & 4.72 \\
\hline & 2 & 15.973 & 117.95 & 15.89 & 5.48 & 15.258 & 114.04 & 14.78 & 4.96 \\
\hline \multirow{3}{*}{$\begin{array}{l}\text { LSD at } \\
5 \% \text { level }\end{array}$} & Potassium & 0.464 & 4.06 & 1.10 & 0.18 & 0.232 & 3.34 & 0.47 & 0.16 \\
\hline & Aquacos & 0.438 & 2.60 & 0.87 & 0.14 & 0.202 & 2.95 & 0.68 & 0.06 \\
\hline & Interaction & NS & NS & NS & NS & NS & NS & NS & NS \\
\hline
\end{tabular}

\subsubsection{Effect of interaction on potassium and nutrient compound}

The interaction amidst potassium as a soil fertilizer and foliar application of nutrient compound had effects on beetroot yield and its composition (Table, 3). The elevated values were listed by using $100 \mathrm{~kg} / \mathrm{fed}$. of potassium fertilizer with foliar spraying of (Aquacool) at altitude level $(2 \mathrm{~cm} / \mathrm{L})$. The statistical analysis of the acquired data restrictive insignificant in total roots yield (tonlfed.), weight root and root length and diameter in both seasons.

\subsection{Root nutritional values}

\subsubsection{Effect of potassium soil fertilizers}

Input recorded in Table (4) clearly indicated that the percentage of N, protein, $\mathrm{P}, \mathrm{K}$. as well as total sugar and vitamin $\mathrm{C}(\mathrm{mg} / 100 \mathrm{~g})$ in dry weight of beetroot tissues were increased with increasing 
potassium fertilizer rates from 0 to $100 \mathrm{~kg} / \mathrm{fed}$. The nutritional values in beetroot tissues forward to capacity the elevated amount with using the high potassium sulfate rate (100 kg/fed..). These feedbacks are in good conformity with the two seasons. Moreover, the statistics test of the acquired data detected that the variation during various potassium levels were major enough to be significant in both seasons. It is clear from data illustrated in Table (4) that the high level of potassium soil fertilizer (100 kg/fed.) significantly improved the percentage of N, Protein, P, K also, total sugar and V.C. contents in both seasons compared to the low potassium fertilizer rate $(50 \mathrm{~kg} / \mathrm{fed} .$.$) and control. It$ could be consummated that, increasing rates of potassium fertilizer in soil solution forward the handiness of nutrient elements which preferable to growing their absorption and as a consequence increased its focus in storage members. The gained results are in good conformity with former investigators like Singh, et al., (2004).

Table 4: Effect of potassium sulfate levels with spray of nutritional compound (Aqucool) in chemical root quality during 2017 and 2018 seasons.

\begin{tabular}{|c|c|c|c|c|c|c|c|c|c|c|c|c|c|}
\hline \multirow{3}{*}{$\begin{array}{l}\text { Potassium } \\
\text { sulfate } \\
\text { (kg./fed.) }\end{array}$} & \multirow{3}{*}{$\begin{array}{l}\text { Spray } \\
\text { Aqucool } \\
(\mathbf{c m} / \mathbf{L})\end{array}$} & \multicolumn{6}{|c|}{2017 season } & \multicolumn{6}{|c|}{2018 season } \\
\hline & & \multicolumn{4}{|c|}{$\%$} & \multicolumn{2}{|c|}{$\begin{array}{c}\text { Mg/100g dry } \\
\text { weight }\end{array}$} & \multicolumn{4}{|c|}{$\%$} & \multicolumn{2}{|c|}{$\begin{array}{c}\text { Mg/100g dry } \\
\text { weight }\end{array}$} \\
\hline & & $\mathbf{N}$ & Protein & $\mathbf{P}$ & $\mathbf{K}$ & $\begin{array}{c}\text { Total } \\
\text { Sugars } \\
\end{array}$ & V.C & $\mathbf{N}$ & Protein & $\mathbf{P}$ & $\mathbf{K}$ & $\begin{array}{c}\text { Total } \\
\text { sugars } \\
\end{array}$ & V.C \\
\hline \multirow{3}{*}{ Without } & $\mathbf{0}$ & 0.63 & 4.15 & 0.10 & 0.89 & 4.25 & 8.40 & 0.35 & 2.17 & 0.09 & 0.95 & 3.65 & 7.39 \\
\hline & 1 & 0.72 & 4.48 & 0.11 & 0.92 & 4.57 & 8.91 & 0.46 & 2.87 & 0.10 & 0.98 & 4.35 & 7.99 \\
\hline & 2 & 0.74 & 4.65 & 0.12 & 0.98 & 5.37 & 9.28 & 0.52 & 3.27 & 0.11 & 1.03 & 4.85 & 8.75 \\
\hline \multirow[t]{2}{*}{ Mean } & & 0.70 & 4.43 & 0.11 & 0.93 & 4.73 & 8.86 & 0.44 & 2.77 & 0.10 & 0.99 & 4.28 & 8.04 \\
\hline & $\mathbf{0}$ & 0.84 & 5.27 & 0.13 & 0.99 & 5.99 & 9.77 & 0.58 & 3.63 & 0.11 & 1.07 & 5.24 & 8.94 \\
\hline \multirow[t]{2}{*}{50} & 1 & 0.85 & 5.31 & 0.15 & 1.04 & 6.18 & 10.20 & 0.67 & 4.17 & 0.12 & 1.12 & 5.57 & 9.44 \\
\hline & 2 & 0.87 & 5.44 & 0.16 & 1.10 & 8.43 & 11.25 & 0.79 & 4.92 & 0.14 & 1.12 & 5.76 & 9.85 \\
\hline \multirow[t]{2}{*}{ Mean } & & 0.85 & 5.34 & 0.15 & 1.03 & 6.87 & 10.41 & 0.68 & 4.24 & 0.13 & 1.10 & 5.52 & 9.41 \\
\hline & $\mathbf{0}$ & 0.90 & 5.81 & 0.18 & 1.13 & 8.98 & 11.08 & 0.83 & 5.22 & 0.14 & 1.13 & 6.15 & 10.32 \\
\hline \multirow[t]{2}{*}{100} & 1 & 0.93 & 5.83 & 0.19 & 1.17 & 9.12 & 11.63 & 0.95 & 5.96 & 0.15 & 1.16 & 6.47 & 10.65 \\
\hline & 2 & 1.14 & 6.40 & 0.21 & 1.24 & 10.60 & 13.33 & 1.03 & 6.42 & 0.16 & 1.18 & 7.42 & 11.25 \\
\hline \multirow[t]{2}{*}{ Mean } & & 0.99 & 6.01 & 0.19 & 1.18 & 9.57 & 12.02 & 0.94 & 5.87 & 0.15 & 1.16 & 6.68 & 10.74 \\
\hline & $\mathbf{0}$ & 0.79 & 5.08 & 0.14 & 1.00 & 6.41 & 9.75 & 0.59 & 3.67 & 0.11 & 1.05 & 5.01 & 8.88 \\
\hline \multirow[t]{3}{*}{ Average } & 1 & 0.83 & 5.21 & 0.15 & 1.04 & 6.62 & 10.25 & 0.69 & 4.33 & 0.12 & 1.09 & 5.46 & 9.36 \\
\hline & 2 & 0.92 & 5.49 & 0.16 & 1.11 & 8.13 & 11.29 & 0.78 & 4.87 & 0.14 & 1.11 & 6.01 & 9.95 \\
\hline & Potassium & 0.07 & 0.30 & 0.01 & 0.03 & 0.30 & 0.48 & 0.03 & 0.19 & 0.01 & 0.01 & 0.68 & 0.37 \\
\hline \multirow{2}{*}{$\begin{array}{l}\text { LSD at } \\
5 \% \text { level }\end{array}$} & Aquacool & 0.06 & 0.11 & 0.01 & 0.01 & 0.46 & 0.43 & 0.02 & 0.15 & 0.01 & 0.01 & 0.24 & 0.12 \\
\hline & Interaction & NS & NS & NS & NS & NS & NS & NS & NS & NS & NS & NS & NS \\
\hline
\end{tabular}

\subsubsection{Effect of foliar spray of nutrient compound (Aquacool) levels}

It is clear from Table (4) that foliar application with different concentrations of nutrient compound (Aquacool) significantly increased the percentage of protein, $\mathrm{N}, \mathrm{P}$ and $\mathrm{K}$ as well as total sugar and V.C. (mg/100g dry weight) of beetroot. The highest content of this nutrient in root tissue were recorded by foliar high level $(2 \mathrm{~cm} / \mathrm{L}$.) of nutrient compound (Aquacool). Such increases may be attributed to that high level of Aquacool contains high amounts of macro nutrients i.e. $\mathrm{N}(7 \%)$, $\mathrm{P}$ $(5 \%), \mathrm{K}(5 \%)$ and $\mathrm{Mg}(1 \%)$ and micro nutrients such as $\mathrm{B}(0.05 \%), \mathrm{Fe}(0.3 \%)$ and $\mathrm{S}(2.1 \%)$ as well as amino acids $(0.2 \%)$. These results were in harmony to with those obtained by El Fouly et al., (2010), Bozorgi et al., (2011) and El-Habbasha et al., (2012).

\subsubsection{Effect of interaction on potassium and nutrient compound}

The interaction between the two levels of potassium soil fertilizer and two levels of nutrient compound (Aquacool) had a slow great effect on the most of chemical nutritional composition of beetroot tissues. Whereas, beetroot plants which received $100 \mathrm{~kg}$ of potassium sulfate and $2 \mathrm{~cm} / \mathrm{L}$ 
foliar spraying of (Aquacool) resulted in the highest N, protein, P, K and total sugar and V.C. contents.

\section{References}

Abd El-Aal, F.S., M.R. Shafeek, A.A. Ahmed and A.M. Shaheen, 2005. Response of growth and yield of onion plants to potassium fertilizer and humic acid. J. Agric. Sci. Mansoura Univ., 30(1): 315-326.

Abou El-Nasr, M.E. and E.A. Ibrahim, 2011. Effect of different potassium fertilizer rates and foliar application with some sources of potassium on growth, yield and quality of carrot plants (Daucus carota L.). Plant Production, Mansoura Univ., 2 (4): 559-569.

Abou-El-Nour, E.A.A., 2002. Can supplemented potassium foliar feeding reduce the recommended soil potassium? Pak. J. Biol. Sci., 5(3): 259-262.

Ali, M.K., M.F. Alam, M.N. Alam, M.S. Islam and S.M.A.T. Khandaker, 2007. Effect of Nitrogen and Potassium level on yield and quality seed production of onion. J. Appl. Sci. Res., 3(12): 1889-1899.

AOAC., 1975. Association Agricultural Chemist, Washington, D.C., 200. Official Method of Analysis $12^{\text {th }}$ Edn., 44: 94-117.

Awatef G. Behairy, Asmaa R. Mahmoud, M.R. Shafeek, Aisha H. Ali and Magda M. Hafez, 2015. Growth, Yield and Bulb Quality of Onion Plants (Allium cepa L.) as Affected by Foliar and Soil Application of Potassium. Middle East Journal of Agriculture, 4 (1): 60-66.

Bhatt, L., B.K. Srivastava and M.P. Singh, 2004. Studies on the effect of foliar application of micronutrients on growth, yield and economics of tomato. Prog. Hort., 36(2): 331-334.

Bozorgi, H.R., A. Ebrahim and M. Maral, 2011. The effects of bio-mineral nitrogen fertilization and foliar zinc spraying on yield and yield components of faba bean. Iran. World Appli. Sci. J., 13(6): 1409-1414.

Brown, J.D. and O. Lilleland, 1946. Raped determination of potassium and sodium in plant material and soil extracts by flame photometery. Proc. Amer. Soc. Hort. Sci., 38: 341-364.

Dias, M.G., M.F.G.F.C. Camoes, and L. Oliveira, 2009. Carotenoids in traditional Portuguese fruits and vegetables. Food Chem., 113:808-815.

El-Fouly, M., M.M. Zeinab and A.S. Zeinab, 2010. Improving tolerance of faba bean duing early growth stages to salinity through micronutrients foliar spray. National Res. Center (NRC), Egypt. Not. Sci. Biol., 2(2): 98-102.

El-Fouly, M.M. and A.A. El-Sayed, 1997. Foliar Fertilization: An environmentally friendly application of fertilizers. Dahlia Greidinger International symposium on "Fertilization and Environment" 24-27 March, Haifa, Israel, Ed. John, J., 346-357.

El-Habbasha, S.F., G. Amal Ahmed and Magda H. Mohamed, 2012. Response of some chickpea varieties to compound foliar fertilizer under sandy soil conditions. Journal of Applied Sciences Research, 8(10): 5177-5183.

Ghaffoor, A. M. S. Jilani, G. Khaliq and K. Waseem, 2003. Effect of different NPK levels on the growth and yield of three onion (Allium cepa L.) varieties. Asian J. Plant Sci., 2(3): 342-346.

Gomez, K.A. and A.A. Gomez, 1984. Statistical procedures for Agriculture Research. Second Ed. Wiley Inter science Publ. John Willey and Sons, New York.

Hegab, A.A., M.A. Mahgoub and A.E. Youssef, 1987. Effect of iron, manganese and zinc on yield, cotton grade and quality of fiber properties of cotton. A gric. Res. Rev., 65: 645-657.

Hussain, M.I., H.N. Asghar, M.J. Akhtar and M. Arshad, 2013. Impact of phosphate solubilizing bacteria on growth and yield of maize. Soil Environ., 32(1): 71-78,

Khan, M.A.M.K.H., M.A.J. Miah, M.M. Alam and A.S.M.H. Masum, 2003. Effect of plant spacing on the growth and yield of different cultivars of onion. Pakistan J. Biol. Sci., 6 18: 1582-1585.

Marschner, H., 1995. Functions of mineral nutrients: micronutrients. In: Mineral Nutrition of Higher Plants. 2nd Ed., Academic Press, London, 313-404.

Pervez, H.M.A. and M.I. Makhdum, 2004. Influence of potassium rates and sources on seed cotton yield and yield components of some elite cotton cultivars. Journal of Plant Nutrition, 27 (7): 1295-1317. 
Peyve, I.B.J., 1969. Participation of micro elements in biochemical process in connection with biosynthesis of protein in plants. Agrokhimia, U.S.S.R. 2:143.

Pregl, F., 1945. Quantitative organic Micro-Analysis. 1 st Ed. J. and A.Churdill Ltd, London.

Roemheld, V., M.M. El-Fouly, 1999. Foliar nutrient application: Challenge and limits crop production. Proc. 2nd International Workshop on "Foliar Fertilization" April 4-10 Bangkok, Thailand: 1-32.

Saud, S., j. Chun, M. Razaq, M. Luqman, S. fahad, M. Abdullah, and A. Sadiq, 2013. Effect of potash levels and row spacing on onion yield. Journal of Biology, Agriculture and Healthcare, 3(16): 118-127.

Savitha, H.R., 2008. Effect of iron on yield and quality of red chilli (capcicum annum L.) in a calcareous vertisol of Zone-8 of Karnataka. M.Sc. Soil Sci. and Agri. Chem. Univ. of Agri. Sci.

Shafeek M.R., M.K.A. Rakha, Asmaa R. Mahmoud and Aisha H. Ali, 2018. Impact of Inoculation with P-fixers bacteria and nutrient compound on growth, yield and nutritional values of garlic plant (Allium sativum L.). Middle East Journal of Agriculture Research, 07(03): 816-825.

Shafeek M.R, Ali Aisha H., Asmaa R. Mahmoud, and Magda M. Hafez, 2016. The influence of foliar and soil fertilization of potassium on growth, yield and quality of garlic plants (Allium sativum L.). International Journal of PharmTech Research, 9(9): 390-397.

Shafeek M.R, Asmaa R. Mahmoud, Aisha H. Ali, Magda M. Hafez and S.M. Singer, 2015. Effect of different levels of potassium applied with foliar spraying of yeast on growth, yield and root quality of turnip under sandy soil conditions. Int .J. Curr. Microbiol .App. Sci., 4(10): 868-877.

Shafeek, M.R., Y.I. Helmy, Awatef, G. Beheiry, Fatma A. Rizk and Nadia M. Omar, 2014. Foliar Application of Some Plant Nutritive Compounds on Growth, Yield and Fruit Quality of Hot Pepper Plants (Capsicum annum, L.) Grown Under Plastic House Conditions. Current Science International, 3(1): 1-6.

Shafeek, M.R., Y.I. Helmy, Nadia, M. Omer and Fatma A. Rizk, 2013. Effect of foliar fertilizer with nutritional compound and humic acid on growth and yield of broad bean plants under sandy soil conditions. Journal of Applied Sciences Research, 9(6): 3674-3680.

Singh, S., P.K. Yadav, and S. Balbir, 2004, Effect of nitrogen and potassium on growth and yield of onion (Allium cepa L.) Cv. Pusa Red. Haryana J. Hort. Sci., 33(3 \& 4): 308 - 309.

Tiwari, R.S., A. Ankur and S.C. Sengar, 2003. Effect of bio regulators, bulb yield, quality and storability of onion cv. Pusa Red. Indian J. Plant Physiol., 8(4): 411- 413.

Troug, E. and A.H. Mayer, 1939. Improvement in the denies colorimetric method for phosphorus and arsenic. Indian Engineering Chemical Annual, 1: 136-139.

Yadav, R.L., N.L. Son and B.L. Yadave, 2003. Response of onion to nitrogen and potassium fertilization under semi-arid condition of Rajasthan. Indian J. Hort., 60(2): 176-178. 